\title{
Pelatihan Pembuatan RPS Berstandar Kerangka Kualifikasi Nasional Indonesia (KKNI) di Era Revolusi Industri 4.0
}

\author{
*Syafrizal ${ }^{1)}$, Ahmad ${ }^{2)}$ \\ ${ }^{1,2)}$ Program Studi Pendidikan Bahasa Inggris Universitas Islam Indragiri, Indragiri Hilir, Riau, Indonesia \\ Email: rizaltlp@gmail.com ${ }^{1}$; ahmadfkipunisi@gmail.com ${ }^{2}$
}

\section{Cara Mensitasi Artikel ini:}

Syafrizal, S., \& Ahmad, A. (2021). Pelatihan pembuatan RPS berstandar Kerangka Kualifikasi Nasional Indonesia (KKNI) di era revolusi industri 4.0. Abdimasy: Jurnal Pengabdian dan Pemberdayaan Masyarakat, 2(2), 68-76. https://doi.org/10.46963/ams.v2i2.440

\section{$\underline{\text { DOI }}$}

https://doi.org/10.46963/ams.v2i2.440

\section{Sejarah Artikel}

Diterima : 05/12/2021

Direvisi : :25/12/2021

Diterbitkan : 31/12/2021

\section{*) Corresponding Author rizaltlp@gmail.com}

\section{Editorial Address}

Kampus Panam (Parit Enam) STAI Auliaurrasyidin, Jl. Gerilya No. 12 Tembilahan Barat, Riau, Indonesia, 29213

abdimasy@stai-tbh.ac.id

\section{Kata Kunci:}

Pelatihan; RPS; KKNI

Keywords:

Training; RPS; KKNI
Abstract: This training aims to improve lecturers competence in constructing RPS and assisting lecturers in compiling the document of RPS. This training was conducted at Islamic University of Indragiri (UNISI) involving 8 lecturers of English Department. This training and mentoring activity was divided into three sessions, first is conveying basic concept of RPS, second is constructing RPS and the third is discussing and presenting RPS. From a series of activities, it can be concluded that the ability of the English department lecturers of Islamic University of Indragiri has increased. This training is also able to correct errors made the lecturer in constructing RPS.

\begin{abstract}
Abstrak: Pelatihan ini bertujuan untuk meningkatkan kompetensi dosen dalam menyusun RPS dan membantu dosen dalam menyusun dokumen RPS. Pelatihan ini dilaksanakan di Universitas Islam Indragiri (UNISI) dengan melibatkan 8 orang dosen Program Studi Pendidikan Bahasa Inggris. Kegiatan pelatihan dan pendampingan ini dibagi menjadi tiga sesi, pertama menyampaikan konsep dasar RPS, kedua menyusun RPS dan ketiga membahas dan mempresentasikan RPS. Dari rangkaian kegiatan tersebut dapat disimpulkan bahwa kemampuan dosen jurusan Bahasa Inggris Universitas Islam Indragiri mengalami peningkatan. Pelatihan ini juga mampu mengoreksi kesalahan yang dilakukan dosen dalam menyusun RPS.
\end{abstract}

\section{PENDAHULUAN}

Perubahan kurikulum selain sebagai kegiatan rutin yang wajib dilakukan memiliki fungsi penting. Pertama, perubahan kurikulum dapat dilihat sebagai kesempatan dan upaya untuk memperolehi dan mengembangkan keunggulan kompetitif. Kurikulum yang diperbaharui secara teratur berfungsi untuk mengantisipasi kebutuhan pasar. Perubahan kurikulum dimaknai sebagai upaya strategis untuk memperoleh keunggulan bersaing. Kedua, perubahan kurikulum dapat dilihat sebagai upaya perbaikan kualitas pendidikan. Dengan perubahan kurikulum diharapkan mutu 
Pelatihan Pembuatan RPS Berstandar Kerangka Kualifikasi Nasional Indonesia (KKNI)

lulusan dapat lebih baik. Dapat disimpulkan bahwa perubahan kurikulum dapat dilihat dalam kerangka meningkatkan daya saing maupun perbaikan kualitas. Hasil dari kedua pendekatan tersebut adalah lulusan yang sesuai dengan kebutuhan(industri) yang pada akhirnya menjamin kelangsungan hidup perguruan tinggi.

Perubahan kurikulum dari kurikulum berbasis isi (content based curricalum) ke kurikulum berbasis kompetensi (competency-based curriculum) berdampak pada perubahan orientasi pembelajaran di perguruan tinggi. Kurikulum berbasis kompetensi (competency based curriculum) berorientasi bahwa pembelajaran di perguruan tinggi tidak hanya menitikberatkan pada pemahaman konsep saja, tetapi menuntut mahasiswa untuk menerapkan konsep yang telah didapat dalam pembelajaran ke kehidupan seharihari. Untuk menghasilkan lulusan yang berkualitas, kurikulum merupakan salah satu instrumen penting dalam proses pendidikan. Sebagaimana tertuang dalam Undang-Undang 2 Nomor 12 Tahun 2012 tentang Pendidikan Tinggi, kurikulum pendidikan tinggi merupakan seperangkat rencana dan pengaturan mengenai tujuan, isi, dan bahan ajar serta cara yang digunakan sebagai pedoman penyelenggaraan kegiatan pembelajaran untuk mencapai tujuan Pendidikan Tinggi. Dengan demikian, tercapai tidaknya tujuan pendidikan akan sangat tergantung dari kurikulum yang diterapkan. Selaras dengan perkembangan ilmu pengetahuan,

teknologi dan seni serta tuntutan ke depan yang makin kompleks, diperlukan suatu sistem kurikulum yang adaptif dan antisipatif terhadap tuntutan zaman, namun demikian mudah diimplementasikan dalam praktis kependidikan. Pada dasarnya penyiapan kurikulum meliputi dua komponen pokok yaitu: (i) komponen kurikulum untuk memberikan bekal kompetensi kependidikan dan (ii) komponen kurikulum untuk memberikan bekal kompetensi substansi materi yang akan diajarkan.

Dalam penyelenggaraan pendidikan di Perguruan Tinggi, Permenristek mengeluarkan Standar Nasional Pendidikan Tinggi (SN-DIKTI) (No. 44 Tahun 2015) sebagai revisi dari Permendikbud No. 49 Tahun 2014 tentang SNPT. SN-DIKTI adalah satuan standar pendidikan tinggi yang meliputi pelaksanaan Tri Dharma

Pendidikan Tinggi yaitu Standar Nasional Pendidikan, Standar Nasional Penelitian, dan Standar Nasional Pengabdian kepada Masyarakat. SNDIKTI ini mengatur tentang standar minimal penyelenggaraan pendidikan, penelitian dan pengabdian pada masyarakat bagi seluruh perguruan tinggi di wilayah hukum Negara Kesatuan Republik Indonesia.

Dengan demikian, secara bertahap perguruan tinggi harus melakukan serangkaian rekonstruksi baik pada tataran kurikulum program studi maupun pada mata kuliah yang diampu oleh dosen dengan merujuk pada KKNI, SN-DIKTI dan Panduan Kurikulum Perguruan Tinggi (KPT) (Kemenristekdikti, 2016). 
Dosen dituntut untuk melakukan rekonstruksi mata kuliah masing-masing yang tertuang dalam Rencana Pembelajaran Semester atau nama lainnya yang disepakati dengan berpedoman pada acuan-acuan di atas. Acuan penulisan RPS sebagai salah satu perangkat pembelajaran di perguruan tinggi adalah Pasal $12 \mathrm{SN}$ DIKTI yang menyatakan bahwa perencanaan proses pembelajaran disusun untuk setiap mata kuliah dan disajikan dalam bentuk rencana pembelajaran semester (RPS) atau istilah lain. Rencana pembelajaran semester (RPS) atau istilah lain ditetapkan dan dikembangkan oleh dosen secara mandiri atau bersama dalam kelompok keahlian suatu bidang ilmu pengetahuan dan/atau teknologi dalam program studi.

Berdasarkan Pasal 12 tersebut, Rencana Pembelajaran Semester (RPS) atau istilah lain minimal memuat: (1) Identitas Mata Kuliah, yang terdiri dari nama program studi, nama dan kode mata kuliah, semester, sks, nama dosen pengampu; (2) Capaian Pembelajaran /Learning Outcomes, yaitu capaian pembelajaran lulusan yang dibebankan pada mata kuliah; (3) Kemampuan Akhir/Learning Objectives, yaitu kemampuan akhir yang direncanakan pada tiap tahap pembelajaran untuk memenuhi capaian pembelajaran lulusan; (4) Bahan Kajian/Materi Pokok, yaitu bahan kajian yang terkait dengan kemampuan akhir yang akan dicapai; (5) Metode Pembelajaran, yaitu cara yang digunakan untuk mencapai tujuan pembelajaran; (6) Alokasi Waktu, yaitu waktu yang diperlukan untuk mencapai kemampuan pada tiap tahap pembelajaran; (7) Pengalaman Belajar, yaitu pengalaman belajar mahasiswa yang diwujudkan dalam deskripsi tugas yang harus dikerjakan oleh mahasiswa selama satu semester; (8) Penilaian, terkait dengan kriteria, indikator, dan bobot penilaian; dan (9) Daftar Bacaan, yaitu daftar referensi yang digunakan dalam proses pembelajaran.

Diperlukan kompetensi yang memadai bagi dosen untuk dapat mengemban Dharma pendidikan dengan profesional sebagaimana dituntut di atas. Dosen dituntut untuk selalu mengembangkan diri mengingat perkembangan dalam kebijakan Pendidikan sangat masif. Berbagai perubahan terjadi dalam penyelenggaraan pendidikan perguruan tinggi terjadi akhirakhir ini dengan pemberlakuan KKNI, SN-DIKTI, dan kebijakan-kebijakan lainnya.

Solusi yang ditawarkan untuk memberikan bekal kompetensi pedagogis terutama terkait dengan perencanaan pembelajaran yang menjadi prioritas pertama untuk dosen-dosen prodi bahasa inggris Universitas Islam Indragiri adalah kegiatan Pelatihan Penyusunan RPS sesuai dengan tuntutan KKNI. Kegiatan pelatihan dilaksanakan dalam tiga tahap, yaitu (1) Penyamaan Persepsi tentang KKNI, dan Penyusunan RPS (2) Tugas Terstruktur Penyusunan RPS dan (3) Presentasi dan Diskusi RPS oleh peserta pelatihan.

Kegiatan pelatihan ini bertujuan untuk (1) meningkatkan kompetensi dosen prodi Pendidikan bahasa inggris Universitas Islam Indragiri (UNISI) Riau dalam merencanakan pembelajaran mata 
Pelatihan Pembuatan RPS Berstandar Kerangka Kualifikasi Nasional Indonesia (KKNI)

kuliah yang diampu berdasarkan KKNI

(2) menyusun Rencana Pembelajaran Semester (RPS) mata kuliah yang diampu.

\section{METODE}

Kegiatan ini dilaksanakan selama 6 hari. Pelatihan dan pendampingan dilaksanakan secara bertahap yaitu pembekalan materi RPS, tugas terstruktur, dan presentasi dan diskusi. Pembekalan materi dilaksanakan pada tanggal 21 dan 22 Juni 2021, pendampingan tugas terstruktur dilaksanakan pada tanggal 23 dan 24 Juni 2021. Kegiatan presentasi dan diskusi dilaksanakan tanggal 25 dan 26 Juni 2021. Kegiatan dihadiri 8 orang dosen prodi Pendidikan bahasa inggris Universitas Islam Indragiri. Kegiatan ini akan dilaksanakan dalam 3 tahapan yaitu pemaparan konsep, rekonstruksi mata kuliah dan penyusunan RPS dan RTM, dilanjutkan presentasi dan diskusi RPS dan RTM. Metode yang digunakan antara lain: Ceramah, Diskusi, Penugasan Terstruktur, dan Presentasi/diskusi. Sedangkan langkah-langkah implementasi untuk mencapai tujuan yang dicanangkan meliputi:

\section{Tahap 1}

1. Penyamaan Persepsi tentang Penyusunan RPS

2. Pemaparan Konsep dan Diskusi tentang RPS

\section{Tahap 2}

1. Rekonstruksi Mata Kuliah dan Penyusunan RPS

2. Dosen melakukan rekonstruksi mata kuliah dan menyusun RPS

3. Penugasan Terstruktur

\section{Tahap 3}

1. Presentasi \& Diskusi RPS

2. Presentasi, Diskusi dan Pemberian Feedback dari narasumber/ fasilitator

\section{HASIL DAN PEMBAHASAN}

Menurut Kamus Besar Bahasa Indonesia, rancangan artinya rencana, program atau desain. Selain itu, rancangan dapat diartikan sebagai rencana yang disusun menurut tahapan tertentu untuk mencapai tujuan yang ditetapkan. Oleh karena itu, rancangan harus dimulai dari penetapan tujuan yang akan dicapai melalui analis kebutuhan, dan kemudian menetapkan tahapan-tahapan yang harus dilakukan untuk mencapai tujuan tersebut. Sedangkan pembelajaran menurut Kamus Besar Bahasa Indonesia, berasal dari kata ajar yang artinya petunjuk yang diberikan kepada orang supaya diketahui (diturut). Sedangkan pembelajaran adalah proses, cara, perbuatan menjadikan orang atau makhluk hidup belajar. Undang-undang Republik Indonesia Nomor 20 Tahun 2003 tentang Sistem Pendidikan Nasional Pasal 1 dan Peraturan Pemerintah Republik Indonesia Nomor 17 Tahun 2010 Pasal 1 tentang Pengelolaan dan Penyelenggaraan Pendidikan mendefinisikan bahwa pembelajaran adalah proses interaksi peserta didik dengan pendidik dan sumber belajar pada suatu lingkungan belajar.

Berdasarkan beberapa definisi di atas dapat disimpulkan bahwa rancangan pembelajaran adalah kegiatan memproyeksikan tindakan yang akan dilaksanakan dalam suatu proses belajar mengajar, yaitu dengan mengkoordinasikan komponenkomponen pembelajaran sehingga tujuan pembelajaran, materi pembelajaran, cara penyampaian kegiatan (metode, model dan teknik), serta bagaimana mengukurnya menjadi jelas dan 
sistematis, sehingga proses belajar mengajar menjadi efektif dan efisien.

Adapun tujuan pembelajaran merupakan substansi utama dari rancangan pembelajaran, oleh karena itu tujuan pembelajaran perlu dirumuskan dengan benar. Tujuan pembelajaran berdasarkan ketentuan yang baru, disebut dengan capaian pembelajaran (learning outcomes). Capaian pembelajaran merupakan internalisasi dan akumulasi ilmu pengetahuan, ketrampilan, sikap, dan kompetensi yang dicapai melalui proses pendidikan yang terstruktur dan mencakup suatu bidang ilmu/keahlian tertentu atau melalui pengalaman kerja. Sedangkan pada ketentuan sebelumnya, tujuan pembelajaran adalah kompetensi, yang dalam ketentuan baru, tujuan ini sudah tercakup. Definisi kompetensi adalah akumulasi kemampuan seseorang dalam melaksanakan suatu deskripsi kerja secara terukur melalui asesmen yang terstruktur, mencakup aspek kemandirian dan tanggung jawab individu pada bidang kerjanya.

Berdasarkan Kerangka Kualifikasi Nasional Indonesia (KKNI), capaian pembelajaran dari proses pendidikan, pelatihan kerja dan pengalaman kerja dikategorikan dalam 9 jenjang (level) kualifikasi dan tiap tiga kualifikasi dikelompokkan dalam satu jabatan, jenjang 1-3 dikelompokkan dalam jabatan operator, 4-6 dikelompokkan dalam jabatan teknisi atau analis, dan jenjang 79 dikelompokkan dalam jabatan ahli.

Rencana Pembelajaran Semester (RPS) adalah kegiatan atau tindakan mengkoordinasikan komponenkomponen pembelajaran sehingga tujuan pembelajaran, materi pembelajaran, cara penyampaian kegiatan (metode, model dan teknik) serta cara menilainya menjadi jelas dan sistematis, sehingga proses belajar mengajar selama satu semester menjadi efektif dan efisien. Berdasarkan Peraturan Menteri Pendidikan Dan Kebudayaan Republik Indonesia Nomor 49 Tahun 2014 Tentang Standar Nasional Pendidikan Tinggi tanggal 9 Juni 2014, komponen Rencana Pembelajaran Semester terdiri dari :

a) nama program studi, nama dan kode mata kuliah, semester, sks, nama dosen pengampu;

b) capaian pembelajaran lulusan yang dibebankan pada mata kuliah;

c) kemampuan akhir yang direncanakan pada tiap tahap pembelajaran untuk memenuhi capaian pembelajaran lulusan;

d) bahan kajian yang terkait dengan kemampuan yang akan dicapai;

e) metode pembelajaran;

f) waktu yang disediakan untuk mencapai kemampuan pada tiap tahap pembelajaran;

g) pengalaman belajar mahasiswa yang diwujudkan dalam deskripsi tugas yang harus dikerjakan oleh mahasiswa selama satu semester;

h) kriteria, indikator, dan bobot penilaian; dan

i) daftar referensi yang digunakan.

Berdasarkan komponen yang harus ada, maka format RPS dapat ditabulasikan. RPS diawali dengan identitas. Selain identitas, pada RPS juga perlu dicantumkan capaian pembelajaran mata kuliah, yang sama dengan yang dicantumkan pada silabus. Sudah barang 
Pelatihan Pembuatan RPS Berstandar Kerangka Kualifikasi Nasional Indonesia (KKNI)

tentu silabus yang dimaksudkan adalah silabus yang sudah dievaluasi berdasarkan Peraturan Menteri No. 49 tahun 2014. Untuk mewujudkan capaian pembelajaran mata kuliah, maka diperlukan pentahapan satu atau beberapa capaian kemampuan yang akan dicapai dalam setiap pertemuan atau sejumlah pertemuan. Tahap kemampuan ini disebut dengan Kemampuan akhir yang direncanakan. Pada dokumen rancangan pembelajaran lama, kemampuan akhir yang direncanakan ini setara dengan kompetensi dasar atau tujuan instruksional khusus, yang telah dilengkapi dengan unsur-unsur yang diprasyaratkan pada KKNI dan SNPT.

Indikator merupakan suatu ukuran yang dapat digunakan untuk menjelaskan kemampuan akhir yang direncanakan. Indikator dalam rencana pembelajaran akan merupakan uraian singkat tentang tingkat kemampuan akhir yang dirinci dalam empat unsur KKNI, yang meliputi sikap dan tata nilai, kemampuan kerja (ketrampilan), penguasaan pengetahuan dan kemampuan manajerial. Kemampuan akhir yang direncanakan tersebut, dapat terdiri dari satu atau beberapa bahan kajian. Bahan kajian tersebut merupakan substansi materi yang akan dibahas pada pertemuan pada perkuliahan, tugas terstruktur dan kegiatan mandiri mahasiswa. Bahan kajian dapat diambil dari pokok bahasan atau bab yang ada pada referensi yang digunakan. Untuk satu bahan kajian dapat digunakan lebih dari satu referensi.

Dari kemampuan akhir yang direncanakan dan bahan kajian yang ditentukan, maka dapat ditentukan metode pembelajaran yang akan dipergunakan untuk mencapai kemampuan akhir yang direncanakan. Metode pembelajaran yang digunakan diusahakan seefektif mungkin, artinya harus dicari metode pembelajaran SCL pada lampiran 2 yang sesuai dengan ranah kemampuan akhir yang direncanakan. Sebagai contoh, jika kemampuan akhir yang direncanakan adalah ranah psikomotorik, maka pembelajaran yang efektif adalah metode Project Based Learning atau praktikum, bukan ceramah atau diskusi.

Tugas mahasiswa adalah aktifitas yang harus dilakukan mahasiswa guna menunjang tercapainya kemampuan akhir yang direncanakan, yang diuraikan secara singkat dan akan dijabarkan lebih rinci pada Rencana Tugas Mahasiswa (RTM) dan Lembar Kerja Mahasiswa (LKM). Sedangkan metode penilaian merupakan uraian singkat tentang cara memberikan penilaian yang didasarkan pada indikator yang telah ditetapkan. Metode penilaian membutuhkan kriteria dan rubrik. Kriteria dan rubrik ini selanjutnya akan dituangkan dalam Lembar Penilaian Hasil Belajar (LPHB). Sedangkan bobot penilaian adalah persentase dari nilai yang didapat untuk suatu kemampuan akhir yang direncanakan terhadap seluruh nilai akhir suatu mata kuliah.

Sebelum pemaparan tentang penyusunan RPS tersebut, peserta diminta menuliskan Capaian Pembelajaran Mata Kuliah CPMK mata kuliah masingmasing, Profil lulusan, dan keberhasilan dalam mengajar selama ini. Dari 8 dosen yang mengumpulkan lembar kerja, belum ada satu pun yang memiliki rumusan lengkap CPMK, yang terdiri dari ABPD 
(Audience, Behaviour, Process, dan Degree). Dilihat dari persyaratan Level 6 dalam KKNI yaitu tujuan mata kuliah minimal (Behaviour) berada pada tingkat Kognitif 3 (C3 Mengaplikasikan), hanya 4 orang yang telah memenuhi syarat tersebut, selebihnya kebanyakan peserta menggunakan tingkat C2 (Memahami) bahkan beberapa dosen menggunakan $\mathrm{C} 1$ (Mengetahui) sebagai tujuan pembelajaran mata kuliah. Dengan demikian, sangat urgen bagi dosen-dosen peserta pelatihan untuk melakukan rekonstruksi mata kuliah mereka masingmasing.

Kegiatan selanjutnya adalah secara bertahap pemaparan materi yang berkaitan dengan penyusunan RPS dengan memberikan contoh-contoh dari mata kuliah yang telah dikembangkan RPSnya. Dari diskusi-diskusi yang dilakukan saat pemaparan khalayak sasaran telah memperoleh pemahaman tentang konsep-konsep penyusunan RPS. Beberapa peserta di akhir sesi menyampaikan mereka memiliki pemahaman lebih jelas tentang aspekaspek dalam penyusunan RPS dari pemaparan dan contoh-contoh yang diberikan.

Kegiatan berikutnya adalah pemberian Tugas Terstruktur selama 3 (tiga) hari untuk menyusun RPS mata kuliah yang dibina. Kegiatan dilanjutkan dengan pendampingan dengan melakukan presentasi dan diskusi. Secara acak peserta diminta untuk mempresentasikan hasil rekonstruksi RPS mata kuliah masing-masing. RPS yang dipresentasikan menjadi bahan diskusi dengan menunjukkan apa yang sudah benar dan apa yang perlu diperbaiki. Peserta diundang untuk berpartisipasi berkomentar tentang RPS temannya untuk pemantapan konsep yang diberikan. Peserta yang terlibat dalam diskusi diminta langsung memperbaiki apabila terjadi kesalahan yang serupa untuk menghemat waktu dan tidak mengulang kesalahan yang sama.

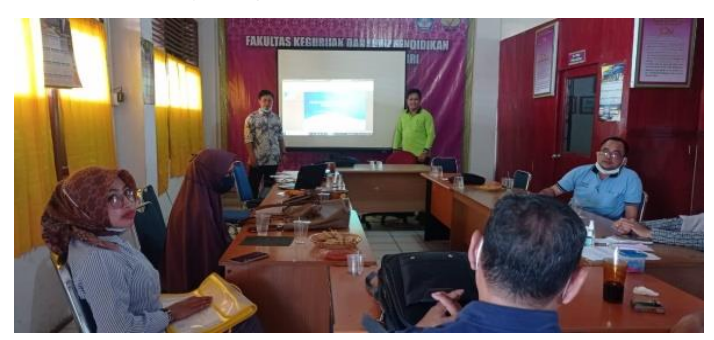

Dari review RPS yang dilakukan pada sesi presentasi dan pendampingan dapat disimpulkan bahwa telah (1) terjadi peningkatan kompetensi dalam penyusunan RPS yang ditandai dengan adanya perubahan-perubahan dalam RPS peserta. CPMK telah dilengkapi dengan unsur-unsur ABPD dan telah diformulasikan dengan benar sesuai dengan tingkatan dan kriteria dalam KKNI dan SN-DIKTI seperti Kata Kerja yang digunakan untuk Level 6 (S1/D4) minimal pada C3 (Menerapkan), beberapa mata kuliah pada semester atas telah menggunakan C4 (Analisis) bahkan C6 (Menyusun); (2) khalayak sasaran telah pula memperbaiki kesalahan-kesalahan konsep tentang penggunaan kata kerja operasional (KKO) dalam pengembangan Indikator Pencapaian, kesalahan pengembangan CPMK menjadi Kemampuan Akhir yang diharapkan (KA), pengembangan KA menjadi Indikator Pencapaian; (3) Permasalahan lain yang ditemukan dari hasil pendampingan adalah pemilihan metode 
Pelatihan Pembuatan RPS Berstandar Kerangka Kualifikasi Nasional Indonesia (KKNI)

dan penilaian pembelajaran. Kebanyakan peserta menempatkan metode Ceramah dan Diskusi sebagai andalan dengan tidak memperhatikan tujuan yang ingin dicapai. Demikian juga dengan penilaian, dua masalah yang dihadapi peserta adalah menentukan teknik penilaian yang tepat dan memberikan bobot pada masingmasing KA. Peserta cenderung menerapkan tes sebagai teknik mayor yang digunakan dalam penilaian. Dengan diskusi yang agak panjang peserta mencoba untuk menyesuaikan metode dan penilaian dengan tujuan pembelajarannya.

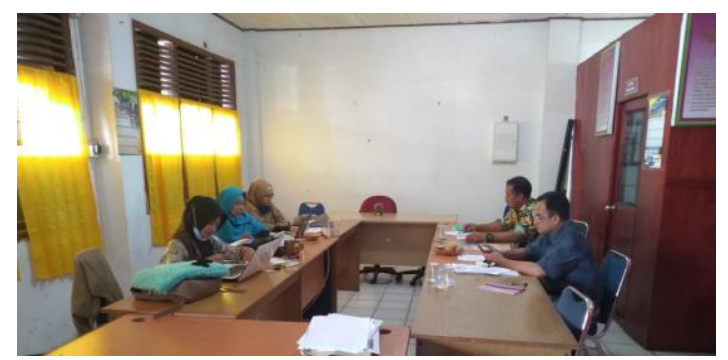

Penyusunan dokumen yang benar dan up-to-date memerlukan proses yang panjang. Dengan bekal yang dimiliki dengan kegiatan pelatihan dan pendampingan ini, khalayak sasaran terus melakukan rekonstruksi RPS mata kuliah yang dibina. Sebagaimana diakui oleh peserta, diperlukan proses Panjang dan harus ditelaah kembali materi-materi yang disajikan maupun yang dikopikan (tidak sempat disajikan).

Untuk membantu khalayak sasaran menyempurnakan dokumen yang mereka kerjakan, kami Tim telah menawarkan bantuan secara online dengan mengirimkan RPS mereka ke alamat email. Dengan demikian, kegiatan Pengabdian kepada Masyarakat ini telah dilaksanakan sesuai dengan rencana kegiatan dan telah mampu meningkatkan kompetensi dosen-dosen Pendidikan bahasa inggris Universitas Islam Indragiri dalam menyusun RPS, serta telah direkonstruksinya RPS mata kuliah yang diampu.

\section{SIMPULAN}

Dari rangkaian kegiatan pelatihan untuk menanamkan konsep, pendampingan, dan presentasi dan diskusi, beberapa dapat disimpulkan bahwa kemampuan khalayak sasaran dosen-dosen Pendidikan bahasa inggris Universitas Islam Indragiri telah meningkat yang ditandai dengan adanya peningkatan dalam menyusun CPMK sebelum kegiatan dilaksanakan dengan CPMK yang dihasilkan pada saat akhir kegiatan. Selain itu, kegiatan presentasi dan pendampingan mampu memperbaiki kesalahan-kesalahan pemahaman pada sesi teori. Dengan melakukan praktik dan presentasi, khalayak sasaran lebih cepat mengenali kesalahan yang dibuat. Selain itu, presentasi dan diskusi bisa menjadi bahan refleksi dan referensi peserta lain.

\section{DAFTAR PUSTAKA}

DIKTI, T. K. (2014). Kurikulum Pendidikan Tinggi. Jakarta:

Direktorat Pembelajaran dan Kemahasiswaan-DIKTI-Departemen Pendidikan Nasional.

Direktorat Jenderal Pembelajaran dan Kemahasiswaan Kementerian Riset Teknologi dan Pendidikan Tinggi.

Peraturan Presiden No 08 Tahun 2012 tentang Kerangka Kualifikasi Nasional Indonesia (KKNI). 
Permenristekdikti No 44 Tahun 2015 tentang Standar Nasional Pendidikan Tinggi (SN-DIKTI).

Permenristekdikti No 55 Tahun 2017 tentang Standar Pendidikan Guru.

Peraturan Pemerintah Republik Indonesia Nomor 17 Tahun 2010 tentang Pengelolaan dan Penyelenggaraan Pendidikan

Peraturan Presiden Republik Indonesia Nomor 8 Tahun 2012 Tentang Kerangka Kualifikasi Nasional Indonesia

Peraturan Menteri Pendidikan Dan Kebudayaan Republik Indonesia, Nomor 49 Tahun 2014 Tentang Standar Nasional Pendidikan Tinggi

Tim Kerja Direktorat Pembelajaran. (2016). Buku Panduan Penyusunan Kurikulum Pendidikan Tinggi.

Undang-undang Republik Indonesia Nomor 20 Tahun 2003 tentang Sistem Pendidikan Nasional. 